\title{
ORBICULAR QUARTZ DIORITE IN KEMI, NW FINLAND
}

\author{
VESA PERTTUNEN
}

\begin{abstract}
PERTTUNEN, VESA, 1983: Orbicular quartz diorite in Kemi, NW Finland. Bull. Geol. Soc. Finland 55, 1, 51-56.

The orbicular rock in Kemi is exposed in one outcrop $10 \mathrm{~m}^{2}$ in size. The country rock is a quartz diorite of the Archean pre-Svecokarelian basement complex. The orbicules are spheroidal or ellipsoidal, 5-16 $\mathrm{cm}$ in diameter, and randomly distributed in a leucocratic quartz diorite matrix. They may have from one to five shells, although the single-shelled varieties are the most common. The contacts of the orbicules with the matrix are sharp, but between the shells and against the core they are gradational. The shells are dioritic. The mafic minerals in them - biotite and hornblende - are radially and tangentially oriented. The majority of the cores are dioritic, but some are ultramafic and rich in biotite. Amphibolite xenoliths have also been found. The Kemi orbicular rock is the first found in Archean bedrock in Finland.
\end{abstract}

Key words: Archean, orbicular rocks, Finland.

Vesa Perttunen: Geological Survey of Finland, PL 77, SF-96101 Rovaniemi 10, Finland.

\section{INTRODUCTION}

An occurrence of orbicular rock was discovered in June 1974 cropping out by a new road at Takajärvi, a suburb of the town of Kemi. The map-sheet is 254108 (Kemi) and the general coordinates $\mathrm{x}=7293.52, \mathrm{y}=$ 528.65. The outcrop is small, being $2.4 \times$ $4.2 \mathrm{~m}^{2}$ in size (Fig. 1). No other outcrops in the neighbourhood exhibit orbicular structures.

The bedrock of the area is part of the Archean pre-Svecokarelian basement complex. The orbicular rock is at a distance of $3 \mathrm{~km}$ from the nearest outcrops of the Early to Middle Proterozoic Peräpohja schist belt. The basement complex consists of mediumto coarse-grained, gneissose rocks from trondjemite and quartz diorite to granite in mineral composition. Amphibolite fragments are common as are diabase dykes cutting the gneisses (Härme 1949; Perttunen 1971).

The orbicules are embedded in a quartz diorite matrix. Two different orbicules were detached for microscopic study. One of them (A) has an ultramafic biotite-rich central core with three surrounding shells. The other (B) has one distinct shell around a dioritic core.

\section{Country rock}

The bedrock around the Kemi orbicular rock is a grey, weakly schistose quartz diorite with xenoliths of amphibolite and biotite-rich schlieren. 


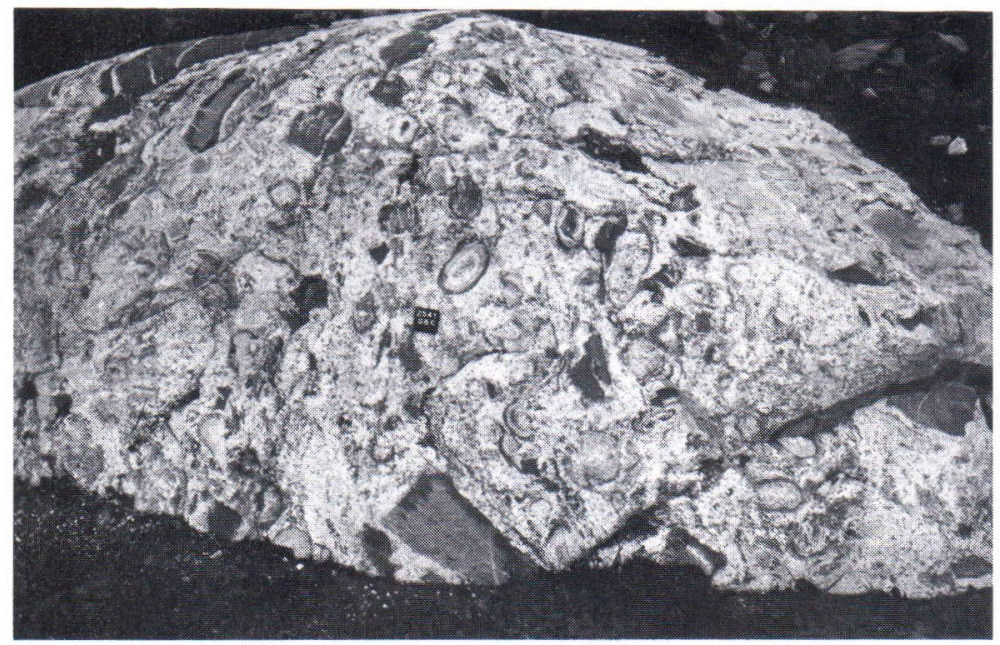

Fig. 1. The outcrop of the Kemi orbicular rock. Plate $6 \times 6 \mathrm{~cm}$.

The mineral composition of the country rock is given in Table 1 . The main mineral is oligoclase, which occurs as subhedral crystals, 1-4 $\mathrm{mm}$ in diameter. The rims are albitic. The amphibole is common green hornblende, and the biotite is pale brown, partly altered into colourless chlorite. Microcline occurs only as small flecks in plagioclase. The other minerals include epidote, titanite and apatite.

\section{Orbicular rock}

\section{Matrix}

The matrix of the orbicules is a leucocratic, heterogeneous quartz diorite (Table 1). The plagioclase is coarse-grained, subhedral oligoclase. The hornblende is green and fresh, and the biotite occurs as pale brown, chloritized flakes. The accessory minerals are epidote, apatite and titanite.

Table 1. Mineral compositions of the Kemi orbicular rock. Vol. \%, point counting method.

\begin{tabular}{|c|c|c|c|c|c|c|c|c|c|}
\hline Rock type & $\mathrm{pl}$ & $\mathrm{qu}$ & $\mathrm{mi}$ & ho & bi & ep & $\mathrm{ti}$ & ap & sum \\
\hline Country rock & 70 & 16 & 1 & 7 & 4 & 2 & + & + & $100 \%$ \\
\hline Matrix & 73 & 19 & 1 & 2 & 3 & 1 & + & - & 99 \\
\hline Shell A3 & 66 & - & - & 5 & 28 & 1 & - & + & 100 \\
\hline Shell A2 & 61 & - & - & 29 & 8 & 1 & + & - & 99 \\
\hline Shell A1 & 75 & 4 & + & 15 & 2 & 2 & + & - & 98 \\
\hline Shell B1 & 74 & 1 & - & 12 & 10 & 2 & - & - & 99 \\
\hline Core A & 5 & 1 & - & 23 & 68 & 2 & 1 & - & 100 \\
\hline Core B & 82 & 5 & + & 11 & - & 1 & + & - & 99 \\
\hline $\begin{array}{l}\text { Amphibolite } \\
\text { xenolith }\end{array}$ & 41 & 20 & - & 31 & 2 & 4 & 2 & + & 100 \\
\hline
\end{tabular}

Mineral abbreviations: pl-plagioclase, qu-quartz, mi-microline, ho-hornblende, bi-biotite, ep-epidote, ti-titanite, ap-apatite.

+ traces, - absent 


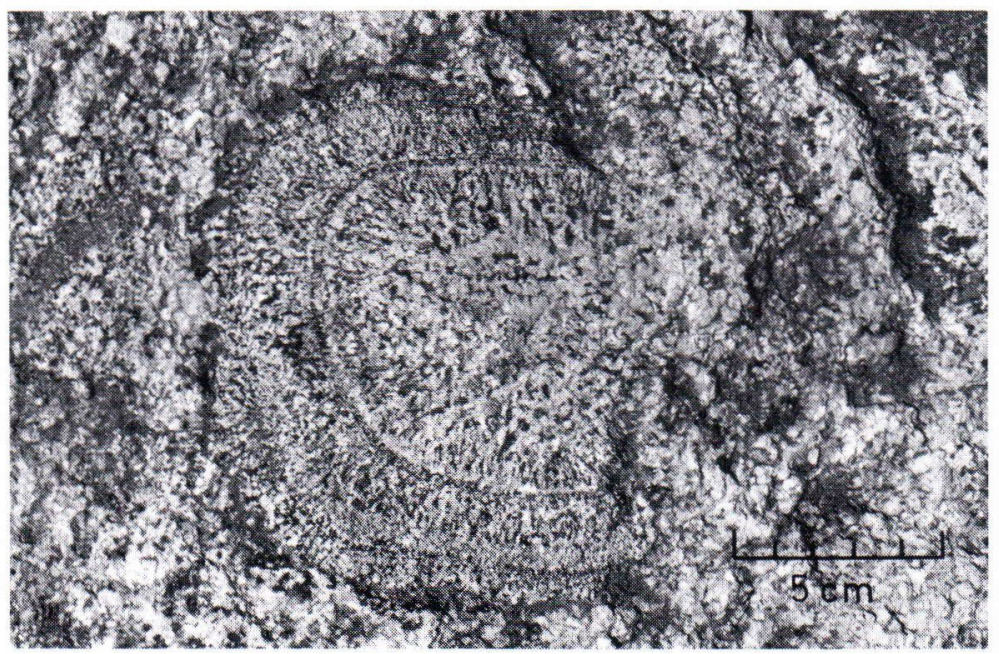

Fig. 2. A partly resorbed orbicule in the Kemi orbicular rock.
In many places plagioclase is more abundant, and the matrix is made up of coarsegrained, plagioclase-rich material digesting the orbicules (Fig. 2).

\section{Orbicules}

The occurrence contains tens of orbicules randomly distributed in the matrix. The orbicules are spheroidal or ellipsoidal, ranging from 5 to $16 \mathrm{~cm}$ in diameter. Except in the partially digested orbicules the contacts with the matrix are sharp (Fig. 2).

The orbicules are of two main types: Type A, with an ultramafic, biotite-rich core surrounded by shells (Fig. 3), and Type B, to which most of the orbicules belong, with a diorite core enveloped by one distinct shell (Fig. 4).

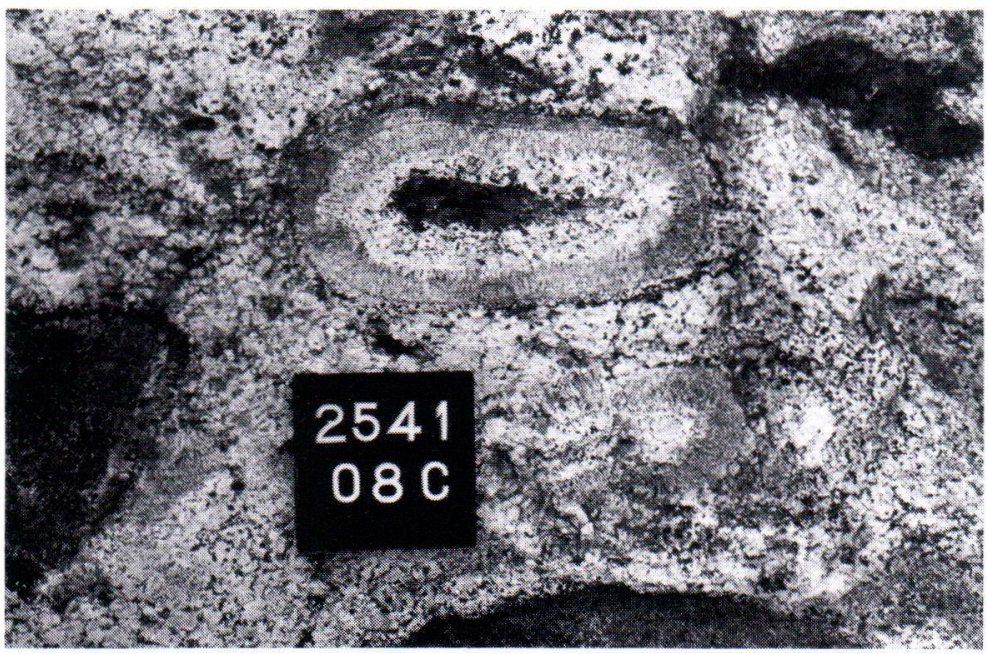

Fig. 3. An orbicule with a biotite-rich central core (Type A) in the Kemi orbicular rock. Plate $6 \times 6 \mathrm{~cm}$. 


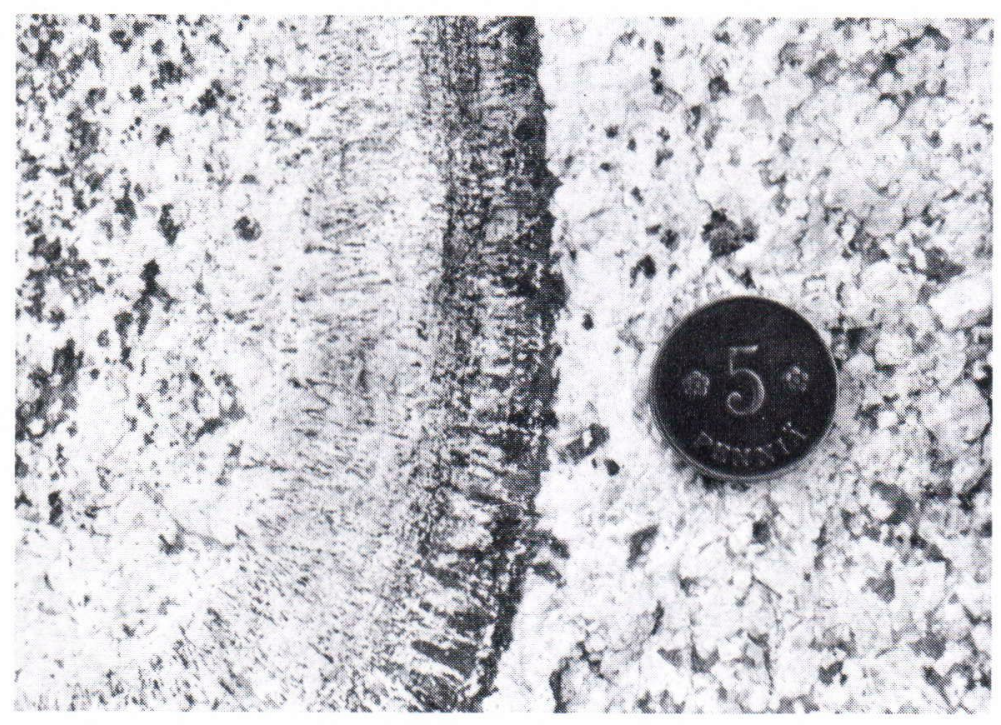

Fig. 4. An orbicule (Type B) with radial and tangential mafic minerals. The diameter of the coin is $1.8 \mathrm{~cm}$.

\section{Core}

The core of the Type A orbicules consists of oriented, ultramafic material, with biotite and hornblende as main minerals. There is little plagioclase (Table 1). The accessory minerals include epidote, quartz, titanite and apatite.

The flakes of biotite are oriented and range in size from 1 to $7 \mathrm{~mm}$. The biotite is light brown and has been altered into chlorite along the boundaries. The amphibole is fresh, common green hornblende, with a grain size from 0.5 to $5 \mathrm{~mm}$.

Most of the orbicules have a coarse-grained, leucocratic diorite core (Type B), with subhedral, weakly zoned andesine-oligoclase, 1-6 $\mathrm{mm}$ in diameter, as main mineral. The hornblende is green and fresh-looking. Biotite is absent, and the amount of microcline negligible (Table 1).

\section{Shells}

The contacts between the shells and against the core are gradational. The mafic minerals, hornblende and biotite, are tangentially and radially arranged (Fig. 4). The grain size is $0.4-3 \mathrm{~mm}$, i.e. smaller than in the matrix and core.

Petrographically the shells are all diorites. The main constituents are oligoclase-andesine, amphibole and biotite. The lack of microcline and the small amount of quartz are common features of the shells. The mineral content of the three Type A shells and the one Type B shell is given in Table 1.

\section{Xenoliths}

The orbicular rock contains frequently fragments of amphibolite that are angular to subrounded (Figs. 1 and 5). The contacts with the matrix tend to be sharp, although some of the fragments have indistinct plagioclasebiotite- hornblende shells.

Sometimes relics of resorbed fragments are indicated by no more than streaks of biotiterich material.

The mineral composition of an amphibolite fragment is given in Table 1. The oligoclase grains have thin albite rims. The texture is crystalloblastic and the grain size $0.4-2 \mathrm{~mm}$. The accessory minerals include pale-green 


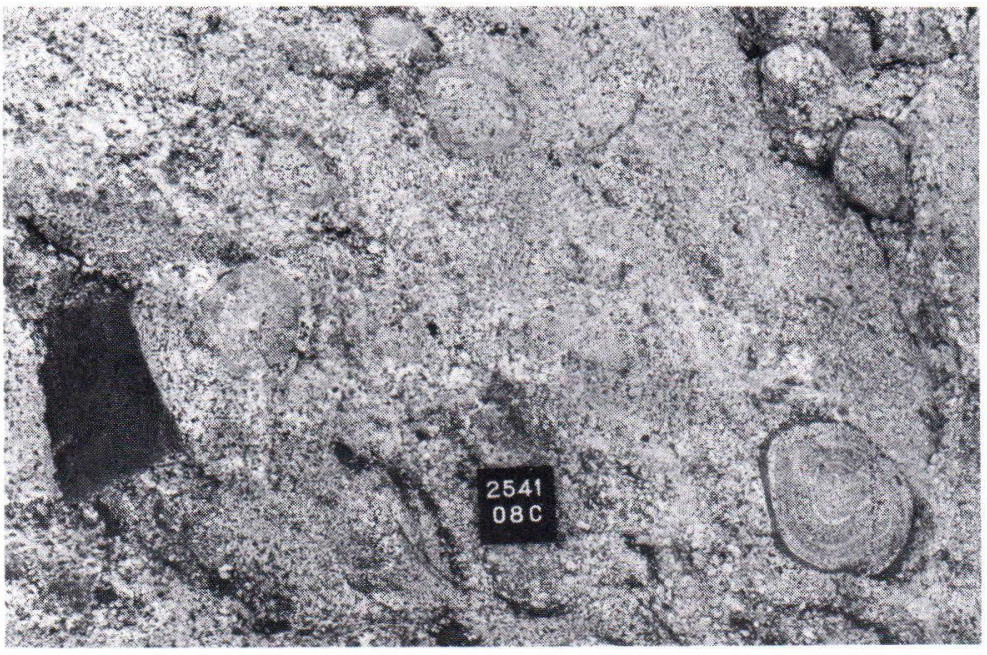

Fig. 5. Orbicules and an amphibolite fragment in the Kemi orbicular rock. Plate $6 \times 6 \mathrm{~cm}$. chlorite, epidote, apatite, sphene and opaques.

\section{Discussion}

Petrographically the country rock and the matrix of the orbicules are quartz diorites, in which quartz is present in considerable amounts but microcline only as an accessory constituent. The orbicules, on the other hand, are diorites, in which the quartz content is low and from which microcline is practically absent. Some of the orbicules even have an ultramafic core.

Megascopically the texture of the country rock and the matrix is weakly schistose, but under the microscope only slight deformation can be seen. The orbicules are undeformed. Only the minerals of the ultramafic cores show parallel texture.

The orbicular rock contains amphibolite xenoliths, most of which show diffuse contacts with the matrix. Some of the xenoliths are surrounded by ind istinct shells, and a few of the orbicules have ultramafic cores, apparently as relics of the xenoliths. Thus the Kemi orbicular rock seems to originate from reactions between the xenoliths and the matrix. Later, the orbicules reacted once more with the matrix (Fig. 2).

Orbicular rocks have been found in nearly 50 localities in Finland (I. Laitakari, pers. comm. January 1983), mostly as boulders. Of the orbicular rocks reported, those at Esbo (Sederholm 1928, Simonen 1941), Kemijärvi (Eskola 1938, Simonen 1938, 1941), Kuru (Simonen 1966), Viitasaari (Pipping 1972) and Virvik (Frosterus 1892, Sederholm 1928) are located in areas affected by Middle Proterozoic granite. The orbicular rock at Maaninka (Pääjärvi \& Söderholm 1979) is associated with a dioritic rock that penetrates the metamorphic supracrustal rocks, probably Archean in age. The orbicular rock at Kemi is the only one found in Finland to date that is situated in Archean terrain without any sign of Proterozoic plutonism. 


\section{References}

Eskola, P., 1938. On esboitic crystallization of orbicular rocks. Jour. Geol. 46, 448-485.

Frosterus, B., 1892. Ueber ein neues Vorkomnis von Kugelgranit unfern Wirvik bei Borgå in Finnland. Min. Petr. Mitt. 13.

Härme, M., 1949. On the stratigraphical and structural geology of the Kemi area, Northern Finland. Bull. Comm. geol. Finlande 147. 60 p.

Pääjärvi, A. \& Söderholm, K., 1979. Uusi pallokiviesiintymä Maaningalla. Geologi 31, 6-7 (in Finnish).

Perttunen, V., 1971. Pre-Quaternary rocks, Sheet 2541 Kemi. Geological Map of Finland $1: 100000$.

Pipping, F., 1972. Viitasaaren kartta-alueen kallioperä. Summary: Precambrian rocks of the Viitasaari map-sheet area. Suomen geologinen kartta
1 : 100 000. Kallioperäkartan selitykset, 2311 Viitasaari. $23 \mathrm{p}$.

Sederholm, J. J., 1928. On orbicular granites, spotted and nodular granites etc. and on the rapakivi texture. Bull. Comm. géol. Finlande 83, $105 \mathrm{p}$.

Simonen, A., 1938. Chemical study of the orbicular rock in Kemijärvi. Bull. Comm. géol. Finlande 123, C. R. Soc. Géol. Finlande 12, 47-49.

Simonen, A., 1941. Orbicular rocks in Kemijärvi and Esbo. Bull. Comm. géol. Finlande 126, C. R. Soc. Géol. Finlande 14, 107-140.

Simonen, A., 1966. Orbicular rock in Kuru, Finland. Bull. Comm. géol. Finlande 222, C. R. Soc. Géol. Finlande 38, 93-107.

Manuscript received, January 4, 1983 